\title{
Ames Assay
}

National Cancer Institute

\section{Source}

National Cancer Institute. Ames Assay. NCI Thesaurus. Code C16235.

An in vivo assay test used to determine if an agent, such as a chemical, is capable of causing mutations in living organisms, and if so, the strength of its mutagenic activity. The procedure uses animal tissue to create active metabolites of the substance which are then tested on bacteria. 